\title{
Comparison of the Sustainable Development of Clothing Industry at Home and Abroad
}

\author{
Lei $Y_{A O}^{1}$ and Zhi-Ying WANG \\ ${ }^{1}$ Beijing Institute of Fashion Technology, Beijing, 100029, China \\ E-mail: sxyyl@bift.edu.cn
}

Keywords: Clothing industry, sustainable development, industrial chain

\begin{abstract}
China suffers about 70,000 tons of textile wastes every day and 2.5 billion tons of wastewater every year. As of 2050, the carbon emission each year of the clothing industry will account for a quarter of that around the globe. However, it is an inevitable trend for the clothing industry to gradually head towards sustainable development amid this rapidly growing modern society in terms of the clothing industry. The studies on the sustainable development of the clothing industry save clothing enterprises from detours and promote their sustainable development by referencing the effective strategies of the clothing enterprises at home and abroad.
\end{abstract}

\section{Introduction}

As early as 1960s, the concept of sustainable development proposed by environmentalists has begun to attract some western European theorists' attention, but it was quite late when the concept was introduced to the textile and clothing industry.

In modern society, the clothing industry boasts a rapidly growth. However, while beautiful and fashionable clothes are produced one by one, pollution and wastes are also increasing day by day. Currently the carbon emission of the clothing industry accounts for $10 \%$ of that around the globe, and it's foreseeable that as of 2050, the percentage will surge to $25 \%$. Globally the largest producer, exporter and consumer of textiles though it is, China is also one of the two largest carbon emitters in the world. China suffers about 70,000 tons of textile wastes every day and 2.5 billion tons of wastewater every year. Therefore, it has become an inevitable trend for the clothing industry, who confronts China with such serious pollution, to gradually head towards sustainable development

This paper first investigates and analyzes the characteristics of the sustainable development of the clothing industries at home and abroad, and then makes comparison between them, in order to provide some references for the sustainable development of Chinese clothing industry.

\section{Analysis of the Characteristics of the Sustainable Development of Chinese Clothing Industry}

Chinese Clothing Industry is characterized by the following 5 aspects, namely, development of environmentally friendly fibers and utilization of the momentum, the increasingly environmentally friendly production part of clothing, rapid development of informatization in the marketing of environmentally friendly clothing, a new and inevitable trend -- cooperation between the upstream and downstream industries and the improved public awareness of environmental protection.

\section{Development of Environmentally Friendly Fibers and Utilization of the Momentum}

In modern society, with a year-by-year growth in the demand for fiber around the world, China, who is globally the largest producer, exporter and consumer of textiles with fast economic development, is at the same time burdened with an increasing shortage of land resources and petrochemical resources, and limited yields of cotton and man-made fiber. Though cotton fiber is our first choice when buying clothes in our daily life, China is troubled by a capped yield of cotton. So China urges all sectors to make greater efforts in developing natural fibers such as environmentally friendly new fibers and bast fibers to address the growing scarcity of fiber resources facing China.

Despite the fact that nowadays quite a lot of clothing enterprises at home have employed the new 
environmentally friendly fabrics, our domestic market, generally speaking, still harbors a negative attitude towards them. Environmentally friendly clothing are mainly favored by urban consumers, who think highly of sustainable fashion, and most consumers in China still belittle environmental protection in the pursuit of trends. Moreover, a majority of clothing companies who advocate sustainable fashion are newly started ones, for example, the famous company New Wide Group. Established in 1975, New Wide Enterprises Co., Ltd. devotes itself to the manufacturing and research of various knitted fabrics, and focuses on the fields of garments and dyeing, casting its trade net all over the world. Recently the Group released the CSR White Paper. According to the White Paper, New Wide Group develops more than 3,000 types of new cloths every year, and it has set up an innovation center which combines cross-industry technologies and sci-tech applications. Mixing the concept of innovation with its goals and missions, New Wide Group has made itself an international textile and garment group spanning Asia, Africa and North America.

\section{The Increasingly Environmentally Friendly Production Part of Clothing}

Being quite important for clothing, the production part can be improved from various aspects. Now China strongly encourages optimizing the clothing production part by upgrading the scientific technologies adopted in the part and cutting down waste of resources and emission of pollutants as much as possible, and appeal to clothing enterprises to build a green supply chain in an appropriate and characteristic way.

ICICLE, a new Shanghai brand, cuts a figure on the strength of the special brand spirit it persists, that is, "comfort, environmental protection and business use". The company develops and creates a lot of products basing on the primary-colored fabrics with a long producing history. Clothing made from primary-colored fabrics, such as primary-colored coats, woolen sweaters and cashmere sweaters, etc. are very popular among the public, and what distinguishes them from the others is that these clothes save the dyeing stage when they are produced, which shields the environment from the pollution when clothes are treated after the dyeing and finishing part.

\section{Rapid Development of Informatization in the Marketing of Environmentally Friendly Clothing}

Informatization in China's clothing industry has developed to a certain degree. For example, New Wide Group has set up a network service platform, which features professional cutting-edge information, fashion trends, online customer service and a variety of exchanging news, etc. With three major systems -- fashion information, sample purchase management and marketing service management, the Group realizes a high degree of informatization. In this way, the upstream and downstream industrial chains can communicate conveniently and efficiently, and the communication between the Group and its customers are greatly streamlined, enabling a multi-angle service for customers.

\section{A New and Inevitable Trend--Cooperation between the Upstream and Downstream Industries}

Let's take bamboo, a kind of fiber, as an example. As one of the natural and environmentally friendly materials abundant in resources, bamboo has successfully arrested people's attention. At present, there are already many companies at home engaging in the production of clothes made from this bamboo pulp fiber. These companies mainly center on the production of underwear and home textiles. Sinotex Investment \& Development Co., Ltd., who has embarked on developing and utilizing bamboo fiber since 2001, has passed the FSC Certification. Currently the company boasts a wide variety of products made from bamboo fiber, and an own green industrial chain by integrating the upstream and downstream chains. Through building close partnership with several companies in terms of clothing development, clothing production and marketing of terminal products, the company boosts its efforts in research and development as well as innovation, including such parts as pulping, spinning, printing and dyeing, promotion and so on. This can not only subdivide the market demands, but also promote the sustainable development of the clothing industry. 


\section{Mobilized Consumption Brought by Improved Awareness of Environmental Protection}

Accompanied by the rapid development in light of the economy and culture, an improving public awareness of environmental protection has become unstoppable. Generally speaking, urban residents in China, a country confronting huge gap of wealth, are often blessed with a better consumption level, a higher education level and a certain awareness of environmental protection, thus, this environmentally friendly clothing often targets at urban consumers.

In 2017, China Chain Store \& Franchise Association collected the opinions of about 100,000 consumers in Ten Chinese Cities in its questionnaire, in which $70 \%$ of the group agreed that "personal consumption will directly influence the environment". In addition, the questionnaire also investigated the factors that affect consumers' choice of sustainable products and services. Among them, "safe and healthy" is prioritized and next comes "environmentally friendly" and "quality".

\section{Analysis on the Characteristics of the Sustainable Development of Foreign Clothing Industries}

In terms of sustainable development, the clothing industries in foreign countries are far ahead of that in China in many aspects, which can be divided into the following parts: the sustainable development status of fast clothing brands, use rate of science and technology as well as the energy, and use rate of second-hand clothing.

\section{A Mature Sustainable Development of Fast Fashion Brands}

Instead of being just a watchword, the concept "sustainable development" penetrates deep inside all sectors in foreign countries, such as in Sweden. The idea of sustainable development of clothing is not limited to the flea markets in various sizes. As far as Swedish fashion brands are concerned, there are outstanding large groups, such as $H \& M$, leading the sustainable development of the fashion industry, and small companies marketing a wide range of environmentally friendly clothing with their unique brand concepts.

The source of $59 \%$ of the cotton used by H\&M is sustainable, and emissions from operations have been further reduced by $21 \%$. The Group has set specific goals for the materials used, namely "two 100\%". Firstly, as of 2020, the source of $100 \%$ of the cotton used by H\&M shall be sustainable. Secondly, as of 2030,100\% of the materials used by H\&M shall be recyclable or from other sustainable sources and by the year end of 2040, the positive climate value chain shall be realized. During 2017, via the “Clothes Collection Program”, H\&M collected 17,771 metric tons of textiles in total for reuse, recycled and reproduction, $12 \%$ more than that collected in 2016, equal to 89 million T-shirts.

\section{Leading Position in Sci-tech and the Use Rate of Energies}

Besides China, America, who bases its current development on scarce resources and serious pollution, is another country with the largest carbon emission in the world. As for its clothing industry, the sci-tech development is first-class all over the world, and the automation rate of its production chain and the machine coverage rate are extremely high. Its clothing enterprises underline elevating the use rate of energies, trying their best to cut down the use of energies.

Let's take Nike, Inc., who takes energy use reduction as a major concept for the sustainable development of the company, as an example. For the purpose of a healthy development in the low-carbon future, Nike shares two key levers with other counties in the world -- energy efficiency (use less energy) and renewable energy (use appropriately). The part that suffers the most carbon emission and energy consumption is in the material phase of the value chain (i.e., the growth and processing of materials), therefore, sustainable industries shall be made good use of, and the product development teams shall choose materials with less adverse impact. Besides, these teams shall be briefed on the importance of good choices for products.

\section{A Higher Use Rate of Second-hand Clothes}

Once a victim of the industrial revolution and with its economy mushroomed by seriously polluted 
the environment several hundred years ago, America has now balanced its economic development with the environment and immersed its citizens in a beautiful and natural environment, accompanied by an increasing awareness of environmental protection among the public. Simplicity is favored by most Americans nowadays. The old and unwanted clothes, shoes and hats, if still wearable, will be sent to stores to be cleaned, sterilized, cleared and refurbished, and then sold to customers or donated to people in need. However, people who frequent these charity shops are not necessarily poor. In fact, people from all walks of life would come here to pick clothes. According to some investigation, most of the incomes of the Millennials in America are swallowed by their house renters and Netflix, only a few of them are used to buy clothes, because most clothes they purchased fall victim to the fast-pace life. An era dominated by second-hand clothes and clothes rent has become the trend.

\section{Comparative Analysis of the Development at Home and Abroad}

The clothing industries at home and abroad differ a lot, as is shown in Table 1.

Table 1 Comparison of the Characteristics at Home and Abroad

\begin{tabular}{|c|c|c|c|c|c|}
\hline & $\begin{array}{l}\text { Organizations } \\
\text { appealing to } \\
\text { environmentall } \\
\text { y } \\
\text { friendly } \\
\text { clothing }\end{array}$ & $\begin{array}{c}\text { Labor resources } \\
\text { and sci-tech } \\
\text { innovation } \\
\text { capacity }\end{array}$ & $\begin{array}{c}\text { Level of } \\
\text { environmenta } \\
\text { l protection } \\
\text { awareness of } \\
\text { enterprises } \\
\text { and the } \\
\text { public }\end{array}$ & $\begin{array}{l}\text { Selection, } \\
\text { recycling and } \\
\text { reuse of } \\
\text { materials of } \\
\text { clothing }\end{array}$ & $\begin{array}{l}\text { Consumers of } \\
\text { environmenta } \\
\text { lly friendly } \\
\text { clothing, } \\
\text { brand } \\
\text { publicity and } \\
\text { marketing }\end{array}$ \\
\hline China & $\begin{array}{l}1 \text { Quite a few, } \\
\text { and are quite } \\
\text { young }\end{array}$ & $\begin{array}{l}1 \text { Abundant } \\
\text { labor resources } \\
2 \text { Sci-tech } \\
\text { innovation is } \\
\text { focused on } \\
\text { fabric R\&D and } \\
\text { the production } \\
\text { part }\end{array}$ & $\begin{array}{l}1 \text { Growing } \\
\text { number of } \\
\text { new } \\
\text { environmenta } \\
\text { lly friendly } \\
\text { clothing } \\
\text { companies } \\
2 \text { Fast } \\
\text { fashion } \\
\text { consumption }\end{array}$ & $\begin{array}{l}1 \text { High } \\
\text { recycling rate } \\
\text { with low } \\
\text { reuse rate }\end{array}$ & $\begin{array}{c}\text { 1Weak } \\
\text { publicity } \\
2 \text { Growing } \\
\text { number of } \\
\text { consumers }\end{array}$ \\
\hline $\begin{array}{l}\text { Foreign } \\
\text { countrie } \\
\text { s }\end{array}$ & $\begin{array}{c}\text { A lot of } \\
\text { international } \\
\text { organizations } \\
\text { about } \\
\text { environmental } \\
\text { protection }\end{array}$ & $\begin{array}{c}\text { Less labor } \\
\text { resources, but } \\
\text { boast high level } \\
\text { of technologies }\end{array}$ & $\begin{array}{c}\text { Foreign } \\
\text { companies } \\
\text { choose } \\
\text { sustainable } \\
\text { development }\end{array}$ & $\begin{array}{l}\text { High } \\
\text { recycling and } \\
\text { reuse rate }\end{array}$ & $\begin{array}{l}\text { Joint efforts } \\
\text { of the whole } \\
\text { industry }\end{array}$ \\
\hline
\end{tabular}

\section{Guide from the State Policy}

As America recently quitted the Paris Agreement, China has received an increasing attention around the globe as an environmentally-friendly country.

To address the pollution facing the textile industry, Chinese government issued the Five-year Plan for National Economic and Social Development (from 2016 to 2020, it's the abbreviation of the " $13^{\text {th }}$ Five-year Plan") in 2016, aiming to recycle 4.5 million tons of textile products by 2020.

However, at a time when the fashion industries all over the world are struggling for a sustainable future, America retreats. It has quitted the Paris Agreement, which was signed by it with China. Donald Trump, the current President of America, has announced earlier that America would withdraw from the agreement and would no longer abide by the provisions made under this 
agreement by the Obama administration. In sharp contrast, China's current Chairman, XI Jinping, is an advocator and strong supporter of the Paris Agreement. Globalization is sweeping the world with an irresistible momentum, and China is seeing an elevation in its international position. Just as what Chairman XI said, Chinas' green hills and clear water are our source of wealth, and we are struggling to become a sustainable country.

\section{Environmental Protection Organizations and Conferences}

In foreign countries, there are many international environmental protection organizations, coupled with various non-governmental organizations launched in early times. However, China has relatively less such organizations, and they are not mature. Environmental protection comes in conflict with economic development, and it takes foreign countries a long time to struggle with pollution-dotted development path after bringing their economies to where they are today. But, given that foreign governments enacted environmentally friendly standard and this triggered people's concern of environmental protection, their non-governmental organizations of all kinds emerged in a very early time. Many international environmental protection organizations, which mainly headquartered in Europe, emerged as the bellwether. Citing OEKO-TEX Association as example, in April 1992, it formulated Oeko-Tex Standard 100, a set of widely applied textile product test standard. The Association was established by two major research institutes, namely Austrian Textile Research Institute and German Hohenstein Institut, and its existing members are famous textile accrediting institutions of countries and their affiliated representative offices. In other words, it has branches in many countries, such as the U.S., Germany, Poland, Sweden, Switzerland, Portugal, Span, Hungary, Italy, Denmark, China, Austria, Slovenia, Japan, South Korea, South Africa, and Turkey. The international environmental protection associations like this have played a leading role in following the environmental protection path for textile industry in the world. However, China has relatively less environmental protection organizations and they are less mature in development than foreign countries. But, there are still various environmental protection conferences in textile industry of China to spur the development of textile industry.

\section{Labor Resources and Scientific and Technological Innovation Abilities}

The volume of waste generated can mirror the productivity of a country. China's textile waste volume accounts for $53 \%$ of the world. It shows that China leads the world in productivity.

China is the second largest country in the world in population. Due to China's extremely rich labor resources, many enterprises choose to manufacture their products in China and then transport products from China to the rest of the world for selling. Although those factories have generated many job for Chinese people, they triggered very serious pollution problems. For example, they partly lead to widely concerned PM 2.5 problems, and the related smog problem has become the top priority one for the public to solve. The pollutant from textile industry has directly adverse impact on environment; if the situation is not improved from the technical perspective, China will struggle with smog problem for more years. In such case, textile industry shall work as pioneer in technical innovation. Currently, China's textile industry mainly focuses its scientific and technological innovation on shell fabric research and development part and production part. China's enterprises tend to launch research and development work in shell fabric, and promote management mode based on systematized information.

Foreign countries have relatively less labor resources, therefore many of them choose to put raw material purchasing part and production part, two parts setting comparatively low technical demand in industrial chain, in factories in South Asia and South Africa with relatively rich labor resources. With local enterprises focusing on parts with high scientific and technological level, corresponding production efficiency is highly improved. Therefore, less textile waste is generated and there is less pollution for environment.

\section{Level of Environmental Awareness}

In terms of level of environmental awareness, enterprises and the public in foreign countries are more advanced than those in China. 
Firstly, from the perspective of the public's environmental awareness, today most of consumers of China attach little importance to the shell fabric of products, in other words, whether the product is environmentally friendly or made of sustainable shell fabric are not that much important. They like to purchase clothing at relatively low price so as to buy more, rather than acre about how many years can the purchased clothing be in service. This phenomenon is especially true to the young with low purchasing power. Living in this society filled with fickleness, people tend to select fast fashion consumption rather than sustainable and environmentally friendly one, which reveals that people are far away from the lifestyle of green consumption.

Secondly, from the perspective of enterprises' environmental awareness, for foreign enterprises choosing sustainable development path, they usually have their own sustainable development report on company and report on enterprise's social responsibility; they formulate a explicit plan on future development once they chose such path; and they continue to recycle and reuse abandoned clothing and second-hand clothing while optimizing and transforming development mode.

\section{Selection, Recycle and Reusing of Raw Material for Clothing}

When making comparison between foreign countries and China in raw material for clothing, the biggest difference turns out to be their attitude toward animal leather.

Selection comes first. Some Chinese are still pride of purchasing animal leather. They have high purchasing power, but they truly look down on life of animal and turn up their nose at environmental protection. In addition, the public who are not interested in animal leather also choose to buy clothing such as shoes and hats made of cony hairs. Despite the pollution generated from the process of producing and processing animal leather, killing animal to getting leather alone can be enough to evidence that what people need are not leather but vanity.

Foreign enterprises generally choose to reject products of animal leather series, vividly revealing that international community resists products of animal leather. Recently, CUIIC announced that it will no more produce products of animal leather series.

Second come the recycle and reusing. The largest trading market of China for second hand clothing is in Guangdong. Mostly, small merchants there purchase second hand clothing for simple processing, and then sell it to consumers with low purchasing power at low price. There are few big-scale clothing enterprises to recycle those clothing in big-scale manner for reusing. In China, it's public service organizations of all kinds to launch activities for and branches of foreign enterprises in China who are engaging in big-scale recycle for reusing. For example, H\&M makes it by organizing second-hand-clothing-for-discount-coupon activity.

In terms of recycling and reusing clothing, foreign countries mainly focus on two aspects. The first one is improving utilization of clothing by charity bazaar, donation, redesign, and so on; the second one is degrading and transforming it into other materials to manufacture new products. In this part, foreign countries have done a more systematic job than China does. For example, they set measure index for recycle and reusing, such as KPI index and index for carbon emission. However, China has not yet formulated any related Chinese-reality-based standard or policy, as a result, its clothing is distributed disorderly.

\section{Consumers, Band Promotion and Marketing of Environmentally Friendly Clothing}

There are differences between foreign countries and China in development of sustainable clothing. This is mainly embodied by what consumer values. To begin with, compared with foreign country, China makes less effort in publicity of sustainable fashion and environmental protection. In addition, China's consumers pay more attention to the safety of products, and their influence on environment, while foreign consumers and enterprises, in addition to those two points, value human rights, animal rights and supply chain management. The publicity related to environmentally friendly clothing in the international community relies on efforts of enterprises and joint cooperation of whole industry. Environmentally friendly clothing have experienced a development accelerated by countless fashion weeks and various awards, such as Green Carpet Fashion Awards launched in Milan in recent years, Reclothing Bank initiated by ZHANG Na (independent designer and the founder of women wear brand Fake Natoo), Innovative Luxury Lab affiliated to Kering Group and 
Shanghai Fashion Week of China.

The second is that more Chinese consumers intend to purchase sustainable and environmentally friendly products, and Chinese market is emerging as the one drawing worldwide attention. Those people are so far mainly middle- and upper-class people, who have strong purchasing power, and pursue lifestyle that is environmentally friendly and natural. Investigations show that their population accounts for about $8 \%$ of the country, which is expected to increase to $31 \%$ in 2030, and then probably to accelerate the increase of China's market price of clothing in retailing to $\$ 5.5040$ trillion.

\section{Inspiration}

\section{There Is Huge Potential Market of Substitutes for Shell Fabric of Animal Leather}

Shell fabric of animal leather comes from animal. And it often turns out that people are more interested in leather from younger animal. However, animal leather trading violates the natural law of respecting life. In addition, a lot of pollutant and waste are to be generated during the production process, which fundamentally comes in conflict with sustainable fashion. Therefore, it's destined to launch research and development on substitutes for shell fabric of animal leather. Today, favorable progress has been made by foreign countries in the new shell fabric of environmentally friendly leather. Made of elements from plants, such as pineapple, corn and coffee, those shell fabric, after processing, touch like the same as shell fabric made of animal leather in terms of style and quality. However, it's very difficult to get products with shell fabric of elements from plants in China today.

\section{The Development Mode of Clothing Enterprises Shall Be Transformed}

Secondly, regarding sustainable fashion, there is still problem about "people". Launching sustainable fashion is doomed to make some staff unemployed. How to engage those staff in sustainable industry while launching sustainable fashion? More thinking shall be given to this question.

\section{More Efforts Shall Be Put To Recycle and Reuse Clothing}

The follow-up work of recycling is underperformed. In specific, it's not clear where the second hand clothing is going. Chinese people are reluctant to reuse second hand clothing, in addition, many large enterprises choose sustainable development path but they are seldom interested in reusing.

\section{The Measurement Index for Sustainable Clothing Shall Be Explicit}

China has not formed its own set of standard to quantize entrance access of second hand clothing and clothing made of environmentally friendly shell fabric. From the perspective of financial index, it's possible to position the environmentally friendly clothing enterprises in a fast and accurate manner. For example, China shall attach more importance to carbon emission and sewage during clothing production process and link it with enterprises' sustainable index, for the purpose to win over consumers' trust in relative products.

\section{The Publicity of Environmentally Friendly Clothing Shall Be Enhanced}

Regarding improvement in the public's environmental awareness, on the one hand, relative knowledge education shall be organized for the public to help them transform to green consumption; on the other hand, technology applied in clothing industrial chain shall be upgraded, related procedures shall be controlled by science and technology, and advantages of quantizing green consumption shall be embodied, enabling the first part of sustainable industry to be innovative from the first place. 


\section{Acknowledgement}

(1) The key project of social science program for Beijing Municipal Education Commission 2016(SZ201610011208)

(2) Beijing Excellent Talents Cultivating Funding Projects "Research on the optimization path of Beijing garment industry structure under the coordinated development of Beijing Tianjin Hebei" (Fund code: TSJH201510012002)

\section{References}

[1] LI Hui. Anti-consumerism and China's Road toward Eco-consumption [J]. Central China Academics, 2016, 03: 72-81.

[2] WANG Fei. Sustainable Fashion [J]. Textile Science Research, 2017, 11:44-46.

[3] SEHN Qing. When Second Hand Clothing Is Even Recyclable, Can Sustainable Fashion Be Far Behind? [J]. CBN Daily, 2015, 06: 2-4.

[4] Marianna. Research on Style of Wayuu People's Textile Product and on Application of Sustainable Design of Fashionable Womenwear (D).Shanghai: Donghua University, 2013

[5] XIAO Wen. Famous Brand like Chanel Are Also Pursuing “Sustainable Fashion” [J]. China Fashion Weekly, 2017, 12: 23-30.

[6] TIAN Hewei. Research on Sustainable Development of Terminal Vitality about Fast Fashion Brand [J]. Progress in Textile Science \& Technology, 2014, 04: 90-92. 